\title{
Characteristics of Vocabulary Use in Narrative Tasks in Preschool Children: A Preliminary Study for AAC Application
}

\author{
Hye-Jung Song ${ }^{\mathrm{a}}$, Yang-Min Song ${ }^{\mathrm{b}}$, Hyun-Ju Park ${ }^{\mathrm{a}}$ \\ ${ }^{a}$ Department of Speech-Language Pathology, Gachon University, Seongnam, Korea \\ ${ }^{b}$ Department of Health Care Management, Gachon University, Seongnam, Korea
}

\author{
Correspondence: Hyun-Ju Park, PhD \\ Department of Speech-Language Pathology, \\ Gachon University, 1342 Seongnam-daero, \\ Sujeong-gu, Seongnam 13120, Korea \\ Tel: $+82-31-750-8881$ \\ Fax: $+82-31-750-8837$ \\ E-mail:phj8747@gachon.ac.kr
}

Received: July 5, 2015

Revised: August 24, 2015

Accepted: September 4, 2015

This work is based on the master's thesis of the first author.

\begin{abstract}
Objectives: Despite the continuous body of research on vocabulary in augmentative and alternative communication, it is difficult to find related studies on vocabulary use in young children. The purpose of this study was to investigate vocabulary use patterns in preschool children by collecting narrative data, and analyzing it by word units. Methods: The subjects were 53 normal children between the ages of 4 and 6 ( 26 boys and 27 girls). Subjects were asked to carry out three narrative production tasks (retelling a story, personal experience, and script). Produced utterances were analyzed for high frequency words according to task type and age group, percentage of core vocabulary in the total vocabulary, percentage of structure words and content words in the core vocabulary, and use and percentage of fringe vocabulary in total tasks. Results: The appearance of high frequency words differed according to task type and age group. Core vocabulary consisted of $72 \%$ of the total word production, representing a large proportion of the total vocabulary. The ratio of structure words to content words was 19:81, showing that content words were more dominant, while the percentage of fringe vocabulary of the total vocabulary was much lower at $7.45 \%$. Conclusion: Vocabulary use in children is affected by the type of task. This study was significant in that it collected narrative utterances to analyze the core vocabulary in preschool children.
\end{abstract}

Keywords: AAC, Narrative, Core vocabulary, Fringe vocabulary 의사소통(communication)은 인간에게 가장 필수적이면서도 기 본적인 삶의 요소이다. 대표적인 수단은 말이며, 이를 통한 의사소 통이 어려운 경우 보완대체 의사소통 체계에 의존할 수 있다. 보완 대체 의사소통(Augmentative and Alternative Communication, $\mathrm{AAC})$ 에 의존하는 사람들은 자발적으로 자신의 어휘를 선택하는 것이 어렵기 때문에, 누군가에 의해 선택되거나 자신의 도구에 미 리 저장된 어휘를 사용해 의사소통을 해야 한다. 따라서 중재 대상 자에게 얼마나 적절한 어휘가 선택되었느냐는 결국 $\mathrm{AAC}$ 중재의 성패를 결정짓는 요인이 된다(Beukelman \& Mirenda, 2005, 2013).

$\mathrm{AAC}$ 중재의 목적은 그 대상자가 다양한 상호작용 속에서 효과 적이고 효율적인 의사소통자(effective and efficient communicator)의 역할을 수행하도록 하는 데 있다. 따라서 AAC 전문가들은
상호작용의 유형에 따른 특성을 파악하고 그 목적을 달성하는 데 필요한 적절한 어휘를 찾아내고자 부단히 노력해왔다. 이들은 특 히 조기 중재의 철학 속에서 어린 아동의 $\mathrm{AAC}$ 중재 프로그램에는 예외 없이 구어와 문어 발달을 지원하기 위한 전략이 반드시 포함 되어야 하며 긴 이야기, 즉 내러티브 산출을 위한 어휘가 필요함을 강조하였다(Beukelman \& Mirenda, 2005, 2013).

내러티브(narrative)는 자신만의 이야기를 생성하거나 들은 이야 기를 다시 말하는, 실제 또는 허구의 성격을 포함할 수 있으며(Crestani, Clendon, \& Hemsley, 2010), 일반적으로 개인적 내러티브(personal narratives), 가상적 또는 상상적 내러티브(fictional or fantasy narratives), 스크립트(scripts) 등으로 구분된다. 개인적 내러티브란 개인의 과거에 일어난 특별한 사건이나 경험에 대한 단일 기억을 이 
야기하는 것이다(Choi \& Han, 2013). 가상적 내러티브란 일반적으 로 실제 경험하지 못하는 허구적인 가상의 소재와 사건에 대한 이 야기를 꾸며 말하는 것이다(Shapiro \& Hudson, 1991; Trabasso \& Nickels, 1992). 스크립트란 일상생활에서 반복적으로 일어나는 일 반적인 사건에 대한 보편적인 표상을 의미한다(Kim, 2013).

어린 아동은 언어습득 이전부터 부모가 책을 읽어 주거나 이야 기를 들려주는 등 수많은 상황에서 내러티브를 접하게 된다. Lee (2004)에 따르면 내러티브는 인간이 세계를 이해하고 구성하는 데 있어서 중요한 매개체 역할을 한다고 한다. 내러티브를 통해 인간은 일관적인 연결성 속에서 자신의 삶과 자아를 구성해 나가며, 타인 의 삶과 행위를 이해할 수 있게 된다는 것이다. Yeom (1999)은 인간 은 자신의 경험에 의미를 부여하며 지식을 구체적으로 말하거나 글 로 써서 관계적인 것을 개념화하기에 내러티브는 개인의 성격뿐 아 니라 문화 전수의 측면에서도 단순한 사건이나 경험 이상으로 중요 하다고 하였다.

내러티브는 미래의 문해 능력과 학업성취로 이어지는 높은 수준 의 언어 기술일 뿐 아니라(Crestani et al., 2010; Hughes, McGillivray, \& Schmidek, 1997; Kaderavek \& Sulzby, 1997; Soto \& Hartmann, 2006), 교실 내 참여와 사회적 상호작용 및 교우관계의 발달 에 크게 영향을 주기에(Crestani et al., 2010; Waller, 2006), 어린 아 동들이 적절한 시기에 다양한 내러티브 유형을 경험하는 것은 매 우 중요하다. 그런데 $\mathrm{AAC}$ 중재를 필요로 하는 의사소통장애아동 들은 경험과 기회 부족으로 인해 내러티브 기술을 발달시키지 못 하는 경우가 많고, 특히 제한적인 어휘 접근의 위험성이 높아 이러 한 상황은 더욱 악화될 수 있다(Crestani et al., 2010). 이는 결국 학 업과 사회적 성취에 부정적 영향을 미침으로써 이들의 삶의 질을 더욱더 저하시키는 요인이 될 수 있다. 따라서 내러티브 경험과 기 술 발달을 촉진하고 이를 뒷받침할 수 있는 충분한 어휘를 제공하 기 위한 노력이 필요하다.

일반적으로 $\mathrm{AAC}$ 중재를 위한 어휘 수집과 선택 과정에서 중요 시되는 자료는 핵심어휘(core vocabulary)와 부수어휘(fringe vocabulary) 목록이다. 핵심어휘는 다양한 사람들에 의해 빈번하게 사용되는 낱말과 메시지를 말하며(Beukelman \& Mirenda, 2005), 이 목록에는 기본적인 욕구 표현이나 간단한 인사말 등의 기능적 인 단어 및 구절들이 포함된다(Grove \& Waker, 1990). 주로 1,000 개 낱말 당 0.5-5회 정도의 출현율을 근거로 삼는다(Kim, Park, \& Min, 2003; Lee, Kim, \& Park, 2005). 부수어휘는 특정 개인이 필요 로 하는 어휘 낱말과 메시지를 말한다. 이 목록에는 개인이 선호하 는 표현, 특정인의 이름, 장소, 활동 등이 포함될 수 있으며, 핵심어 휘 목록에 나타나지 않는 개별적인 아이디어 및 메시지의 표현을
가능하게 한다(Beukelman \& Mirenda, 2005). 이상적으로 AAC 사용자가 필요로 하는 어휘 항목을 선택하고자 할 때 이들 두 어휘 목록을 우선적으로 고려하는 것이 중요하다.

그 중요성에도 불구하고, $\mathrm{AAC}$ 중재를 위한 어휘 선택 과정에서 참고할 수 있는 핵심어휘 목록을 제시한 국내 연구는 Kim 등(2003) 과 Lee 등(2005)에 불과하다. Kim 등(2003)은 초등학생, 중학생, 고 등학생, 성인을 대상으로 학교에서의 쉬는 시간과 일상생활에서 자 발화를 수집하였다. 그 결과 학령기 아동 및 성인의 핵심어휘들 간 에 $53 \%$ 가 일치하는 것으로 나타났으며 상위 고빈도 25 개 어휘는 전체어휘의 $34 \%$ 를, 50 개의 어휘는 전체어휘의 $58 \%$ 를 차지하는 것 으로 나타났다. 초등학교에서 일반 아동의 대화를 수집해 분석한 Lee 등(2005)에 따르면, 학교상황에서 산출한 아동의 핵심어휘는 전체어휘의 $81.3 \%$ 를 차지하는 것으로 나타났다. 또한 부수어휘의 비율은 그리 높지 않았지만, “또래와 자유롭게 이야기를 시작하고 유지하는 데 중요한 촉매제 역할을 한다(Lee et al., 2005)”고 제안 하였다. 이 외에도 $\mathrm{AAC}$ 어휘와 관련하여 국내에서는 주로 특정 주 제 및 상황에서 어휘 사용 패턴이 어떻게 나타나는지를 파악한 연 구들이 진행되어 왔다. 장애 유무와 상관없이 학령기 아동과 성인 이 주로 연구대상자로 참여하였고 설문조사나 대화를 수집해 분석 하는 방법이 사용되었다. Park (1996)은 설문조사를 통해 뇌성마비 학생의 어휘를 수집하였다. Park (1999)은 다양한 환경에서 지적장 애 학생과 일반 학생의 기능적 어휘를 수집하였다. Cheon (2000)은 $\mathrm{AAC}$ 체계 활용을 위해 초등학생을 대상으로 지역사회 중심의 기 초어휘 및 문장을 조사해 장소에 따라 어휘일치도와 어휘다양도, 문장 범주 등이 다르게 나타남을 확인하였다.

$\mathrm{AAC}$ 사용자의 내러티브 중재를 염두에 두고, 내러티브 과제를 이용해 핵심어휘 목록을 제시하고자 하는 연구들 또한 수행되기 시작했다. 그 예는 Caton, Crowe와 Haar (2003), Crestani 등(2010) 에서 찾을 수 있는데, 이들은 내러티브 과제를 제시하고 어휘를 수집 한 후 발화당 평균 단어 수와 총 단어 수를 산출하였다. 특히 Crestani 등(2010)은 이야기 다시 말하기 과제에서 원작에 포함된 어휘 와 아동이 산출한 어휘를 직접 비교하였다. 이들은 5-6세 일반 아 동으로부터 총 145 개의 내러티브 샘플을 수집하여, 총 6,679개의 어휘를 분석한 후, 상대적으로 적은 핵심어휘 173 개가 총 어휘 수 의 많은 부분(80\%)을 차지함을 확인하였다. 또한 내러티브 과제를 통해 수집한 핵심어휘는 대화나 설문조사를 통해 수집한 기존 핵 심어휘 목록과 차이가 있음을 발견하였다. 이를 통해 연구자들은 내러티브 산출을 위한 어휘 선택을 위해서는 다양한 내러티브 과 제를 통한 어휘 수집이 필요함을 강조하였다.

지금까지 이루어진 국내 어휘 연구를 종합해보면, 주로 학령기 
이후 일반아동이나 장애아동을 대상으로 어휘 능력을 비교하거나 설문조사와 대화체를 통한 핵심어휘 연구에 국한되어 있음을 알 수 있다. 또한 기존에 제시된 어휘 목록은 오래 전에 발표된 자료들 로서 $\mathrm{AAC}$ 중재를 위한 어휘 선택 과정에서 문화와 시대적 민감성 을 충족시키기 어려운 측면이 있다. 연령 적절성을 고려하기에 어려 운 측면 또한 존재한다. 따라서 학령전기 어린 아동을 대상으로 $\mathrm{AAC}$ 중재를 이행할 때 참고할 수 있는 어휘 관련 정보가 매우 필요 하다. 특히 AAC에 의존하는 아동들의 내러티브 산출을 돕기 위한 적절한 어휘 선택 시 도움을 받을 수 있는 정보는 전무한 상황이다. 이에 본 연구에서는 이야기 능력이 급속히 발달하는 4-6세 일반아 동을 대상으로 내러티브 과제를 이용해 발화를 수집하여 어휘 낱 말을 분석하고 그 특성을 파악하고자 하였다. 특히 내러티브 과제 에서 공통적으로 빈번하게 나타나는 핵심어휘 목록을 작성하고 이 것이 내러티브 과제를 포함하지 않은 선행 연구들에서 제시한 핵심 어휘 목록과 어떠한 차이가 있는지를 살펴봄으로써 AAC 사용 아 동의 내러티브 산출을 돕기 위한 어휘 항목 선정 시 참고할 수 있는 구체적인 정보를 얻고자 하였다. 이러한 목적을 달성하기 위한 연구 문제는 다음과 같다.

1) 내러티브 과제 유형 및 연령집단(4-6세)에서 나타나는 고빈도 어휘는 무엇인가?

2) 내러티브 과제 전체에서 나타나는 핵심어휘는 무엇인가?

3) 핵심어휘에서 나타나는 구조어와 내용어의 비율은 어떠한가?

4) 부수어휘가 전체 어휘에서 차지하는 비율은 어떠한가?

\section{연구 방법}

\section{연구대상}

서울 지역 어린이집에 소속되어 있는 학령기 이전 4-6세 일반 아 동 60 명(남 30명, 여 30명)이 연구에 참여하였다. 이들은 부모와 교 사에 의해 정상발달로 보고되었으며, 수용표현 어휘력 검사 $(\mathrm{Re}-$ ceptive and Expressive Vocabulary Test, REVT; Kim, Hong, Kim, Jang, \& Lee, 2009)에서 -1 표준편차 이상인 정상 발달 범주에 속하 였고, 장애가 있거나 행동문제를 지니지 않은 아동들이었다. 60 명 의 아동에게 내러티브 과제를 주고 이들의 발화를 녹음하였으나 발화 수가 적고(과제당 10 낱말 미만), 음질 문제로 전사가 어려운 아동의 발화는 분석에서 제외하였다. 그 결과 Table 1 에 제시된 바 와 같이, 4 세 집단 19 명(남아 10 명, 여아 9 명), 5 세 집단 18 명(남아 8 명, 여아 10 명), 6 세 집단 17 명(남아 9명, 여아 8 명) 등 총 54 명(남 27 명, 여 27명)의 아동 자료가 분석에 포함되었다.
Table 1. Participants' characteristics

\begin{tabular}{lccc}
\hline & Group 1 (N=19) & Group 2 (N=18) & Group 3 (N=17) \\
\hline Age (mo) & $54(3.09)$ & $65(3.01)$ & $77(2.93)$ \\
Gender (male:female) & $10: 9$ & $8: 10$ & $9: 8$ \\
REVT (standard score) & & & \\
Receptive vocabulary & $60.05(4.04)$ & $67.65(4.21)$ & $77.05(4.49)$ \\
Expressive vocabulary & $58.10(4.61)$ & $66.85(4.99)$ & $75.95(3.89)$ \\
\hline
\end{tabular}

Values are presented as mean (SD) or number

REVT=Receptive Expressive Vocabulary Test (Kim, Hong, Kim, Jang, \& Lee, 2009).

\section{검사기간}

본 연구는 REVT와 자료수집을 포함하여 2014년 9월 4일부터 11 월 25일까지 약 3 개월에 걸쳐 실시되었으며, 각 아동 당 $30-45$ 분 정도의 발화가 녹음되었다.

\section{연구 도구 및 장소}

아동의 발화를 수집하기 위해 녹음기(SONY ICD-UX543)를 사 용하였으며, 어린이집 특성상 주변 아동의 말소리나 다른 소음들로 인해 대상 아동의 발화를 녹음하는 데 어려움이 없도록 빈 교실에 서 일대일로 연구를 진행하였다.

\section{연구 절차}

4세 집단 아동에게는 두 가지 내러티브 과제(개인적 경험말하기 와 이야기 구성하기 과제)를 제시하였고, 5 세와 6 세 집단 아동에게 는 세 가지 내러티브 과제(이야기 다시 말하기, 개인적 경험말하기, 이야기 구성하기)를 제시하였다. 이는 Hughes 등(1997)의 내러티 브 유형 분류에 따른 것으로 과제 간 중복되는 내용은 없었다. 과제 제시 순서는 아동에 따라 역균형화(counter balancing)하였다.

\section{이야기 다시 말하기}

이야기를 선정할 때, 널리 알려진 전래동화를 제외하였고, 창작동 화 가운데 인과적 사건들로 연결된 이야기를 우선적으로 모색하였 다. 그 결과, Lee (2003)의『하나가 길을 잃었어요』가 선정되었으며, 이를 30 문장 이내로 간추려 아동에게 들려준 후 이야기 이해를 확 인하기 위한 6 가지 질문을 하여 이야기에서 언급된 정보를 이해했 는지 확인하였다. 아동이 부정확하게 답하거나 답을 모를 경우 연구 자가 정확한 답을 알려 주었고, 아동에게 이야기를 한 번 더 들려 주 었다. 이야기를 두 번째로 들려주기 전에 연구자는 아동에게 "나중 에 다른 친구들이 이 이야기를 들을 수 있도록 $\bigcirc \bigcirc$ 의 목소리를 녹 음할 거야.”라고 말하였다. 이야기를 다 듣고 난 후 아동에게 다시 이 야기해보도록 유도하였고 이를 전사하여 어휘를 분석하였다. 

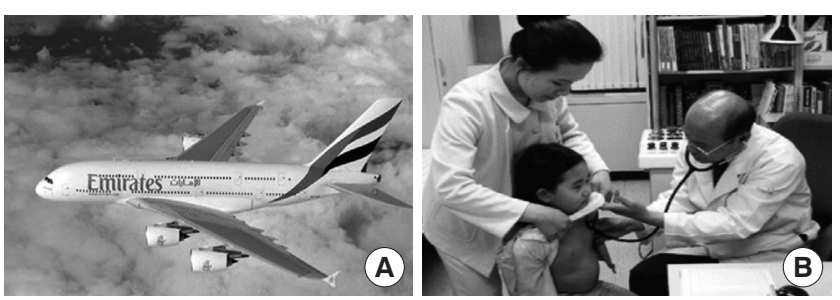

Figure 1. Photos for personal experience task: (A) flight, (B) to go to see a doctor.

개인적 경험 말하기

아동에게 10 장의 사진(비행기, 상처, 수영장, 병원, 조부모, 버스, 생일파티, 놀이터, 치과, 산타; Figure 1)을 보여 준 뒤 사진과 관련된 개인적인 경험을 이야기하도록 유도하였다(예: “○○야, 병원에 가 본 적 있니?”. 아동의 발화는 이후 분석을 위해 모두 녹음하였다.

\section{이야기 구성하기}

일련의 연속적인 그림카드 4 컷(총 5 개의 주제: 꼬마와 솜사탕, 게 임과 지각, 고양이와 생선, 크리스마스와 선물, 토끼와 동굴; Figure 2)을 제시하고 아동에게 그림을 연결해서 순서대로 이야기를 해줄 것을 지시한 뒤 이를 녹음하였다.

\section{발화 분석}

녹음을 통해 수집된 아동의 발화는 '한글 2010'에서 전사한 후, 전사한 어휘의 오류를 살펴보기 위한 작업을 거쳤다. 전사한 자료 는 이후 'Microsoft Excel'에서 축약어휘로 전환하고 빈도와 빈도 율을 산출하였다. 핵심어휘는 1,000 낱말 중에서 0.5 번 이상 출현한 낱말(Beukelman, Jones, \& Rowan, 1989)로 세 집단에서 모두 공통 적으로 사용되는 어휘로 선정하였다. 녹음된 발화는 낱말 단위로 분석하여 전사원칙에 따라 입력하였으며, 입력된 낱말은 축약어휘 로 전환하여 분석하였다(Appendix 1 참조). 전사와 축약어휘 전환 원칙 및 어휘분석 과정은 다음과 같다.

\section{전사원칙(Stuart, Vanderhoof, \& Beukelman, 1993)}

(1) 반복되는 어휘는 그대로 포함시켜 전사하도록 한다.

(2) 실제 어휘가 아닌 발성은 전사시 표시하도록 한다.

(3) 숫자는 전사하도록 한다.

(4) 고유 명사도 전사에 포함시키도록 하며, 이때 호칭도 포함시 키도록 한다.

(5) 전사시, 대화에서 사용된 문장이 불분명하면 일부 어휘를 알 아들었다고 하더라도 그 문장 전체를 전사에서 제외시키도록 한다.
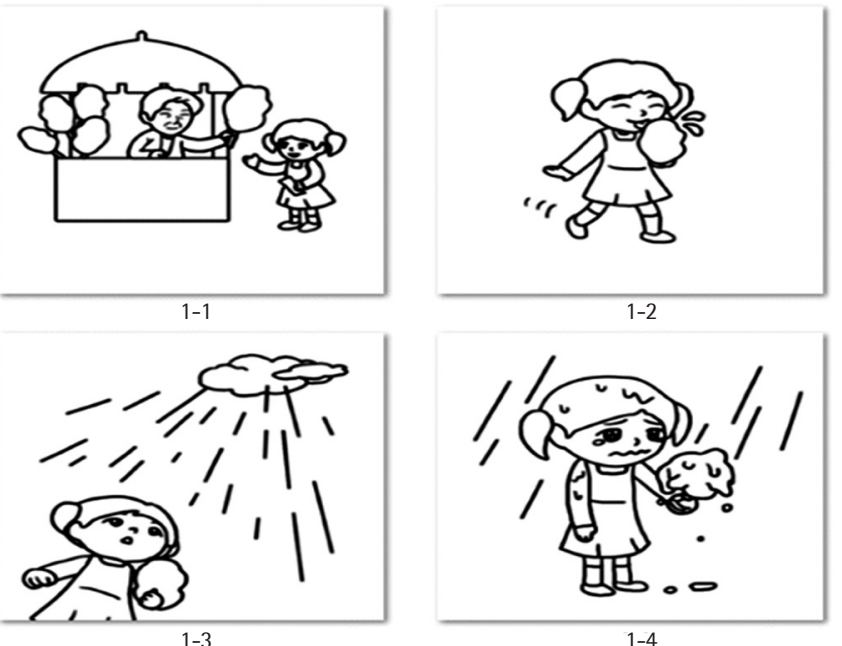

Figure 2. Pictures for script narrative task (cotton candy).

(6) 분석 작업으로 넘어가기 전에 전사한 어휘의 오타를 확인하 도록 한다.

축약어휘 전환 원칙(Lee et al., 2005)

(1) 동사는 시제와 높임말의 구분 없이 원형으로 나타낸다.

(2) 동사와 접속사가 결합되어 있는 경우, 동사와 접속사를 원형 으로 나누어서 기록한다.

(3) 본동사와 보조동사가 결합되어 하나의 개념으로 쓰인 경우 이 는 하나의 동사로 간주하고 나타낸다(예: 가져가다, 가져오다).

(4) 본동사와 보조동사가 모두 동사 전체의 뜻에 기여하는 경우, 각 동사의 원형을 각각 기록한다(예: 집어주다 $\rightarrow$ 집다+주다, 올려두다 $\rightarrow$ 올리다+두다).

(5) 존대어는 평어의 형태로 나타낸다.

(6) 친구나 형제의 이름이 나타나는 경우, '사람이름'으로 기록한 다. 단, 위인이나 방송인 및 유명인, 영화나 만화에 등장한 인 물이름은 그대로 표기한다

(7) 자연스럽게 입에서 나오는 언어음(言語푭)은 축약어휘에서 제외한다.

(8) 다른 품사에서 전용되어 습관적으로 빈번히 쓰이는 간투사 는 축약어휘에 제외한다.

(9) 수는 한글로 읽었을 때 의미를 담고 있는 단위로 나누어 기록 한다.

(10) 조사와 같은 문법형태소는 축약어휘에서 제외하며 어휘형 태소만을 대상으로 한다. 
어휘 분석

(1) 빈도 분석: 낱말이 출현한 빈도를 중심으로 과제 및 연령 집단 별 고빈도 순위를 산출하였다. 빈도수가 동일한 경우 가나다 순으로 정렬하였다.

(2) 핵심어휘 선정: 1,000 낱말 중에서 0.5 번 이상 출현하면서 세 연령 집단에서 공통적으로 사용되는 낱말을 핵심어휘로 선 정하고, 빈도 순으로 제시하였다.

(3) 핵심어휘가 전체어휘에서 차지하는 비율 분석: 핵심어휘 중 상위 $10,50,100,150,200$ 개의 고빈도 어휘가 전체어휘에서 차지하는 비율을 계산하여 어느 정도의 적은 어휘가 전체 어 휘를 대표할 수 있는가를 살펴보았다.

(4) 구조어와 내용어의 비율 분석: 핵심어휘를 중심으로 구조어 (대명사, 관형사, 접속사)와 내용어(명사, 동사, 형용사, 부사) 의 비율을 분석하였다.

(5) 부수어휘 선정: 전사한 자료에서 핵심어휘를 제외한 어휘 가 운데 아동이 참여하는 활동, 관심사항 및 선호도, 환경 및 자 신이 속한 집단을 반영해주는 어휘를 부수어휘로 선정하였다.

\section{신뢰도}

연구자는 수집된 발화가 전사 및 축약어휘 전환 원칙에 의해 신 뢰롭게 처리되었는지를 검증하기 위해 분석자 간 일치도를 산출하 였다. 연구자와 두 명의 분석자(언어병리학 석사 수료)는 사전에 전 사 및 축약어휘 전환 원칙을 숙지한 상태였으며 전체 자료 중에서 무작위로 $20 \%$ 를 선정해 전사하고 축약어휘로 전환하였다. 그 결과 분석자 간 일치도는 각각 $93.3 \%, 95.1 \%$ 로 나타났다.

\section{연구 결과}

\section{과제 및 연령 집단별 고빈도 어휘}

과제별 고빈도 어휘

내러티브 상황에서 나타나는 고빈도 어휘를 산출하기 위해 이야 기 다시 말하기, 개인적 경험 말하기, 이야기 구성하기 과제로 나누 어 고빈도 어휘 목록을 작성하였다.

이야기 다시 말하기 과제에서 고빈도 어휘는 '개구리', ‘그래서', ‘엄마', '하다', '장화', '하나(인물)', '있다', '전화', '할머니', ‘그런데’ 등 으로 나타났다. 원작과 중복되지 않는 어휘 목록에서 가장 높은 빈 도로 사용된 어휘는 인과관계를 나타내는 접속사 '그래서'였다. 전 체낱말수(NTW) 1,650 개 중 원작의 어휘와 중복된 낱말 수는 1,199 개로 72.7\%였으며, 다른낱말수(NDW) 261개 중 중복된 낱말 수는 133 개로 $51.0 \%$ 를 차지하였다.
개인적 경험 말하기 과제를 통해 산출된 어휘 중 서로 다른 10 개 의 주제에서 공통적으로 포함된 고빈도 어휘는 '있다', '하다', '가 다, '그런데', ‘나', '때', ‘그래서', '그리고', '타다', '엄마' 등으로 나타 났다. 다른 두 내러티브 과제와 비교했을 때 '나'와 ‘때'의 출현이 두 드러졌다. 아동에게 제시한 10 개의 주제 중 가장 많은 어휘를 이끌 어 낸 주제는 ‘수영'과 '조부모'에 관련된 사진이었으며, ‘비행기'와 '버스' 사진을 보고 산출한 어휘 수가 가장 적었다.

이야기 구성하기 과제에서는 이야기 다시 말하기 과제와 마찬가 지로 '그래서'가 가장 많이 사용되었으며 그 다음으로는 '있다', '그 런데', '가다', ‘하다', ‘먹다', ‘그리고', ‘주다', ‘솜사탕', ‘토끼' 등의 순 이었다.

과제별 고빈도 어휘를 살펴보면, 과제의 특성이 반영되어 특정 내러티브 과제에서만 출현하는 어휘들이 있었다. 예를 들면 '하나', ‘땅보할머니', '개구리'는 이야기 다시 말하기 과제에서만 출현하였 고, ‘할아버지', ‘할머니', '생일'은 개인적 경험 말하기 과제에서만 나 타났으며, ‘토끼', ‘고양이', ‘솜사탕'은 이야기 구성하기 과제에서만 출현하였다. 그러나 '그래서', ‘그런데', ‘그리고'와 같은 접속 부사와 '하다, 가다, 있다'와 같은 동사는 모든 과제에서 산출되어 내러티브 과제 수행에 중요한 어휘임을 알 수 있었다. 구체적인 과제별 고빈도 어휘는 Appendix 2에서 찾아볼수 있다.

\section{연령 집단별 고빈도 어휘}

연령이 높아질수록 전체낱말수(NTW)와함께 다른낱말수(NDW) 가 증가하였으며 어휘다양도(TTR)는 적은 차이를 보였다. 5 세 집 단은 이야기 다시 말하기 과제에서 산출된 다른낱말수(NDW) 126 개 가운데 중복되지 않는 어휘는 75 개로 59.5\%였으며, 6세 집단의 경우 다른낱말수(NDW) 135 개 가운데 중복되지 않는 어휘는 89개 로 $65.92 \%$ 수준으로 원작에 포함된 어휘의 영향을 덜 받았다.

연령이 높을수록 구체적인 시간에 관련된 어휘를 자주 사용하 였으며, 다양한 접속사를 사용하였고, '이', '그', '저'와 같은 관형사 의 사용빈도가 높게 나타났다(Appendix 3 참조).

\section{핵심어휘}

내러티브 상황에서 나타나는 4-6세 아동의 핵심어휘를 산출하 기 위해 세 가지 과제(이야기 다시 말하기, 개인적 경험말하기, 이야 기 구성하기)에서 수집한 축약어휘를 종합하여 빈도를 산출하였 다. '있다', ‘그런데', ‘하다', '가다', '그래서', ‘그리고', ‘나', ‘엄마', ‘때', '주다' 등이 상위 핵심어휘로 나타났다. 구체적인 핵심어휘 목록은 Appendix 4에서 찾아볼수 있다. 


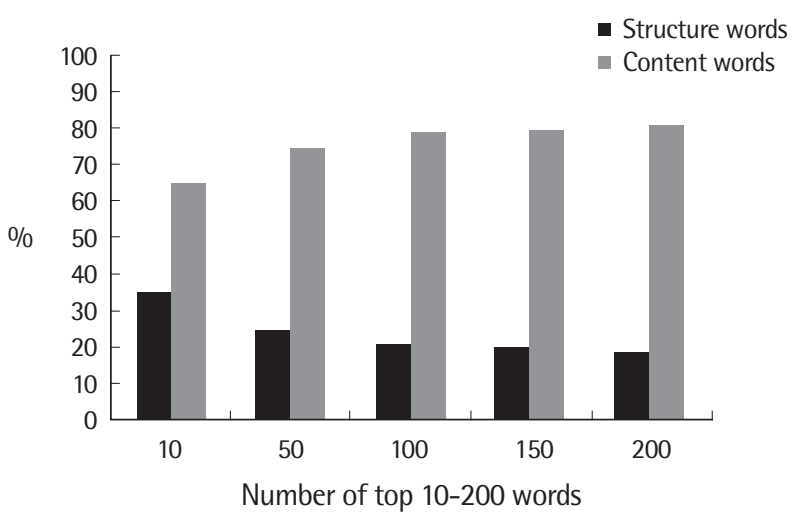

Figure 3. Percent of content words and structure words.

\section{핵심어휘가 전체낱말에서 차지하는 비율 및 구조어와 내용어 비율}

핵심어휘 목록을 살펴보면, 다른낱말수(NDW)는 212개로 아동 의 전체 발화에서 산출된 어휘의 다른낱말수(NDW) 5,761 개의 $3.72 \%$ 에 불과하지만, 핵심어휘가 전체낱말수(NTW)에서 차지하 는 비율은 $72 \%$ 이었다.

아동이 산출한 고빈도 어휘 중 1,000 낱말당 0.5 번 이상 출현한 핵심어휘의 품사별 출현빈도를 살펴보면, 핵심어휘의 다른낱말수 (NDW)에서는 명사 105 개(49.06\%), 대명사 8개(3.74\%), 동사 62개 (29.90\%), 부사 21 개(9.81\%), 형용사 11 개(5.14\%), 관형사 4 개(1.87\%), 기타 1 개( $0.47 \%)$ 로 나타났다. 핵심어휘의 전체낱말수(NTW)에서 는 명사 4,653 개(36.98\%), 대명사 612개(4.86\%), 동사 4,476개(35.58\%), 부사 2,295개(18.24\%), 형용사 431 개(3.43\%), 관형사 103 개(0.82\%), 기타 11 개(0.09\%)로 나타났다.

총 12,565 개의 전체 어휘 중에서 명사, 동사, 부사가 차지하는 비 율은 $90.8 \%$ 로 내러티브 상황에서 아동은 명사, 동사, 부사 범주의 어휘를 높은 빈도로 사용하였다.

Figure 3에서 볼 수 있는 바와 같이, 구조어(대명사, 접속사, 관형 사)와 내용어(명사, 동사, 형용사, 부사)의 비율을 분석한 결과, 상위 10 개의 핵심어휘에서 구조어와 내용어의 비율은 35:65로 나타났고 50 개의 핵심 어휘에서 구조어와 내용어의 비율은 25:75로 나타났 다. 100 개의 핵심어휘에서는 $21: 79$ 의 비율이었고, 150 개의 핵심어휘 에서는 20:80이었으며, 200 개의 핵심어휘에서는 19:81로 내용어가 차지하는 비율이 월등히 높았다. 따라서 본 연구에서는 빈도가 높 을수록 구조어 비율이 높은 반면 어휘 수가 증가할수록 내용어 비 율이 증가함을 알수 있었다.

\section{전체 과제에서 나타나는 부수어휘와 그 비율}

내러티브 과제에서 $4,5,6$ 세 아동이 산출한 부수어휘와 그 비율
을 알아보기 위해, 전사한 자료를 근거로 아동이 선호하는 활동 및 장소, 표현을 반영하는 어휘를 조사하였다. 아동들이 산출한 부수 어휘의 전체낱말수(NTW)는 1,295 개로 전체 어휘의 $7.453 \%$ 를 차 지하였고, 다른낱말수(NDW)는 479개로 다양한 어휘들이 부수어 휘에 포함되는 것으로 나타났다. 부수어휘 목록의 구체적인 예는 Appendix 5에서 찾아볼수 있다.

\section{논의 및 결론}

본 연구에서는 $\mathrm{AAC}$ 사용 아동의 내러티브 산출을 염두에 두고 메시지를 구성할 때 참고할 수 있는 어휘자료를 얻기 위해, 4-6세 일반아동을 대상으로 세 가지 내러티브(이야기 다시 말하기, 개인 적 경험 말하기, 이야기 구성하기) 과제를 사용해 발화를 수집하고 어휘를 분석해 그 특성을 파악하고자 하였다. 내러티브 과제 유형 과 연령집단에 따른 고빈도 핵심어휘와 부수어휘를 중심으로 연구 결과를 논의하면 다음과 같다.

첫째, 과제별로 산출된 고빈도 어휘는 내러티브 과제의 유형에 영향을 받는 것으로 나타났다. 이야기 다시 말하기 과제에서 나타 난 어휘(NDW)는 원래 이야기에 포함된 어휘의 $51 \%$ 로 대략 절반 정도에 해당하였다. 이는 $\mathrm{AAC}$ 사용자가 이야기를 다시 말하고자 할 때, 자신의 $\mathrm{AAC}$ 체계에 원래 이야기에 포함된 어휘들만을 지니 고 있을 경우 이야기 구성에 어려움이 있을 수 있음을 보여준다. 이 야기 다시 말하기와 원래 이야기 간 중복되지 않은 어휘 중에서는 '그래서'가 가장 빈번하게 사용된 것으로 나타났다. 개인적 경험 말 하기 과제에서는 '있다'가 가장 많이 사용되었다. 다른 내러티브 과 제와 비교했을 때 개인적 경험 말하기 과제에서는 '나'와 '때'의 빈 도가 특히 높았다. 따라서 내러티브 과제의 유형이 어휘의 출현 빈 도에 크게 영향을 미친다는 점을 알 수 있다. AAC 중재 대상자가 자신의 경험을 말하고자 할 때 '나'를 포함해 자신을 둘러싼 중요한 어휘들이 자신의 $\mathrm{AAC}$ 체계에 포함돼 있지 않다면 적절한 내러티 브 산출에 실패할 것이다. 따라서 이들이 다양한 경험과 사건들을 표현하고자 할 때, 이를 뒷받침할 수 있는 어휘들을 그들의 어휘 목 록에 포함시키는 것은 매우 중요하다.

둘째, 연령 집단별 전체낱말수는 4 세 집단 4,940 개, 5 세 집단 5,728 개, 6 세 집단 6,654 개였으며 다른낱말수는 4 세 집단 1,537 개, 5 세 집단, 1,901 개, 6 세 집단 2,223개로, 연령이 높아질수록 전체낱말 수와 함께 다른낱말수가 증가하였다. 이야기 다시 말하기 과제에서 원래 이야기와 중복되지 않는 어휘는 5 세 집단 $59.5 \%, 6$ 세 집단 $65.92 \%$ 로 연령이 높을수록 원래 이야기에 포함된 어휘의 영향을 덜 받았다. 또한 연령이 높을수록 '그래서', '그런데', '그리고', '이', 
'그, '저'의 사용 빈도가 높았다. 이는 Crestani 등(2010)의 연구와 유사한 것으로, 연령집단이 아동의 어휘사용에 영향을 준 것으로 보이며, 연령이 높아질수록 접속사와 관형사의 사용 빈도가 높아 짐을 알 수 있다. 이는 $\mathrm{AAC}$ 중재에 있어서 연령에 따른 $\mathrm{AAC}$ 사용 자의 어휘 항목 선정이 어떻게 달라지는지 그리고 이들의 연령에 따 른 어휘 요구의 변화에 지속적으로 반응하는 것이 얼마나 중요한 지를 보여주는 것이다.

셋째, 본 연구에서 얻어진 핵심어휘 목록은 기존 연구에서 제시 된 핵심어휘 목록과 비교할 때, 접속사의 빈도가 높다는 점에서 뚜 렷한 차이가 있다. 초등학교 3학년 아동을 대상으로 대화체를 수집 한 Lee 등(2005)의 연구에서 제시된 상위 핵심어휘는 '하다', '나', '이거', '야', '너', '되다, '것', '안', '친구이름' 등이었고, 초등학교 3-4 학년 아동을 대상으로 대화체를 수집한 Kim 등(2003)의 연구에서 는 ‘하다', '나', '것', ‘너', ‘야, '있다' '보다', '안', 애', '가다' 등이 상위 핵심어휘로 나타난 반면, 본 연구에서는 '있다', '그런데', ‘하다', '가 다, '그래서', ‘그리고', '나', '엄마', '때', '주다' 등이 상위 핵심어휘로 선정되었다. 기존의 어휘목록과 비교하여 내러티브 과제에서 접속 사의 빈도가 현저히 높게 나타나 내러티브를 산출하고자 하는 AAC 사용자에게 필요한 어휘 항목을 제공하고자 할 경우 내러티브 과제 를 활용한 어휘 리스트를 반드시 참고해야함을 알 수 있다.

또한 본 연구에서 핵심어휘의 다른낱말수는 212 개로 아동의 전 체 발화에서 산출된 어휘의 다른낱말수의 $37.2 \%$ 에 불과하지만, 핵 심어휘가 전체 어휘에서 차지하는 비율은 $72 \%$ 였다. 소수의 핵심어 휘가 전체어휘의 많은 부분을 대표한다는 것은 기존의 연구와 일 치한다. 이를 통해, $\mathrm{AAC}$ 중재 대상자를 위한 어휘 항목 선택 시 핵 심어휘 목록의 활용은 $\mathrm{AAC}$ 중재 제공자의 시간과 노력을 크게 줄 여주는 유용한 방법임을 다시 한 번 확인할 수 있다. 그럼에도 불구 하고, 국내의 경우 $\mathrm{AAC}$ 중재를 위한 어휘 선택 과정에서 참고할 만 한 핵심어휘 목록은 찾아보기 어렵다. 특히 지난 10 년 동안 발표된 핵심어휘 목록은 전무한 상황이다. 어휘 항목은 연령과 문화 등 여 러 요인의 영향을 크게 받기 때문에 다양한 상황과 과제를 통한 핵 심어휘 목록을 개발하고자 하는 연구들이 꾸준히 이루어져야한다.

넷째, 상위 10 개의 핵심어휘에서 나타난 구조어와 내용어의 비 율은 35:65로 나타났고, 전체 핵심어휘에서 나타난 구조어와 내용 어의 비율은 19:81로, 내용어가 차지하는 비율이 더 높았다. 빈도가 높을수록 구조어의 비율이 증가하는 반면 어휘수가 늘어날수록 내용어의 비율이 증가한 것으로 나타났다. 이는 Kim 등(2003)의 연구 결과와 유사하다. 그러나 고빈도 어휘 50 개 중 구조어 33 개, 내 용어 17 개로 구조어의 비율이 더 높았다고 보고한 Crestani 등(2010) 의 연구와는 차이가 있다. Crestani 등(2010)은 MacWhinney (1995)
의 정의에 따라 관사, 전치사, 대명사, 접속사를 구조어에 포함시킨 반면 본 연구에서는 관형사, 대명사, 접속사만을 구조어에 포함시켰 기에 이러한 차이가 나타났을 것으로 판단된다. 따라서 구조어와 내용어를 단순 비교하는 것을 넘어 좀 더 다양한 언어적 요소를 검 토함으로써 일상 대화뿐 아니라 내러티브 산출을 지원할 수 있는 어휘사용 정보를 파악할 필요가 있다.

다섯째, 부수어휘가 전체어휘에서 차지하는 비율은 $7.45 \%$ 로 높 지 않게 나타났다. 이러한 결과는 학령기 일반아동을 대상으로 조 사한 Lee 등(2005)과 지적장애 성인을 대상으로 조사한 Park (2009) 의 연구 결과와 유사하다. 부수어휘는 개개인의 선호도 및 자신이 누구인지를 드러내는 데 있어서 매우 중요하다. 따라서 $\mathrm{AAC}$ 중재 제공자는 그 출현율에 상관없이 부수어휘 목록에 대한 관심을 기 울여야만 한다.

내러티브 구성 능력은 이후 학업과 문해 능력에 영향을 미치는 중요한 기술로 간주된다. 특히 4-6세 아동들은 내러티브 구성 능력 을 급속도로 발전시킨다. 따라서 이 시기 아동들이 다양한 내러티 브 구조를 경험하는 것은 매우 중요하다. 이는 어린 AAC 사용자들 에게 특히 해당되는 사항이다. 다행히 본 연구 결과는 내러티브 구 조를 생성하기 위해 많은 핵심어휘가 필요하지 않으며, 과제 및 연 령을 고려한 어휘 선택이 중요함을 보여주었다. 이는 전문가들이 $\mathrm{AAC}$ 체계를 구성할 때 기존의 어휘목록을 참고하되, 내러티브 산 출을 또한 고려하여 중재 대상자가 개별적으로 필요로 하는 적절 한 어휘를 제공하기 위해 노력해야함을 시사하는 것이다.

본 연구는 한정된 내러티브 과제에서 아동이 산출한 발화를 수 집하였으므로 내러티브에 필요한 다양한 어휘를 완전히 수집하였 다고 단정하기 어렵다. 또한 구조어에 속하는 어미, 접사, 조사 등의 형태소는 분석에서 제외하였기에 본 연구 결과를 일반화하는 데는 주의가 필요하다. 앞으로 후속연구에서는 다양한 내러티브 과제 및 상황을 통해 어휘를 수집하고, 학령기로 갈수록 더욱더 확대되 는 내러티브 산출 능력을 고려하여 학령기 이후 대상자에 대한 내 러티브 수행 어휘를 분석하여 그 추이를 살펴볼 필요가 있다. 또한 대화 상대에 따라 변화하는 어휘 사용 측면을 비교하기 위해 다양 한 연령대의 대화상대를 투입해 발화를 수집하고 분석해보는 연구 가 필요하다. 마지막으로, 내러티브 과제를 통해 수집된 핵심어휘 와 부수어휘가 $\mathrm{AAC}$ 사용자의 실제 내러티브 산출 활동에 적절히 활용될 수 있는지를 검증하기 위한 중재연구 또한 이루어져야 할 것이다. 본 연구는 $\mathrm{AAC}$ 사용자의 내러티브 산출을 조기에 돕고자 하는 의도에서 학령전기 어린 아동을 대상으로 대화체가 아닌 내 러티브 과제를 활용해 직접 발화를 수집하고 핵심어휘 목록을 제 시했다는데 그 의의가 있다. 


\section{REFERENCES}

Beukelman, D., \& Mirenda, P. (2005). Augmentative and alternative communication: supporting children and adults with complex communication needs (3rd ed.). Baltimore, MD: Paul H. Brookes Publishing.

Beukelman, D., \& Mirenda, P. (2013). Augmentative and alternative communication: supporting children and adults with complex communication needs (4th ed.). Baltimore, MD: Paul H. Brookes Publishing.

Beukelman, D., Jones, R., \& Rowan, M. (1989). Frequency of word usage by nondisabled peers in integrated preschool classrooms. Augmentative and Alternative Communication, 5, 243-248.

Caton, M., Crowe, L., \& Haar, S. (2003). Comparison of children's story retelling after one or three readings. Poster session presented at ASHA Annual Convention, Chicago, IL.

Cheon, C. K. (2000). A research on basic vocabularies and sentences in the community for utilizing augmentative and alternative communication (AAC) system (Master's thesis). Dankook University, Yongin, Korea.

Choi, Y. J., \& Han, D. O. (2013). A case study on a one-year-old infant's personal narrative during picture book reading. Journal of Children's Literature and Education, 14, 375-397.

Crestani, C. A. M., Clendon, S. A., \& Hemsley, B. (2010). Words needed for sharing a story: implications for vocabulary selection in augmentative and alternative communication. Journal of Intellectual and Developmental Disability, 35, 268-278.

Grove, N., \& Walker, M. (1990). The Makaton vocabulary: using manual signs and graphic symbols to develop interpersonal communication. Augmentative and Alternative Communication, 6, 15-28.

Hughes, D. L., McGillivray, L., \& Schmidek, M. (1997). Guide to narrative language: procedures for assessment. Eau Claire, WI: Thinking Publications.

Kaderavek, J. N., \& Sulzby, E. (1997). Oral narratives and emergent bookreadings of typically developing and language impaired children. Paper presented at the Annual Meeting of the National Reading Conference, Scottsdale, AZ. Kim, H. N. (2013). A study on the personal narrative of children in the 3-yearold class shown in the conversational activities about the kindergarten experience (Master's thesis). Korea National University of Education, Cheongju, Korea.

Kim, Y. T., Hong, K. H., Kim, K. H., Jang, H. S., \& Lee, J. Y. (2009). Receptive \& expressive vocabulary test (REVT). Seoul: Seoul Community Rehabilitation Center.
Kim, Y. T., Park, H. J., \& Min, H, K. (2003). School-aged children and adults' core vocabulary for the development of an augmentative and alternative communication tool. Korean Journal of Communication Disorders, 8, 93110.

Lee, H. J. (2003). Hana got lost. Seoul: Sigongsa.

Lee, H. J. (2004). A study on the educational applications of narrative curriculum. Korean Journal of Educational Research, 10, 151-170.

Lee, Y. M., Kim, Y. T., \& Park, Y. H. (2005). A preliminary study for the core and fringe AAC vocabulary used by elementary school students. Korean Journal of Communication Disorders, 10, 134-152.

MacWhinney, B. (1995). The CHILDES project: tools for analyzing talk (2nd ed.). Hillsdale, NJ: Erlbaum.

Park, H. Y. (2009). Study of semantic usage of language by the mentally retarded adults living in group home through the analysis of the core and fringe vocabulary (Master's thesis). Ewha Womans Universiy, Seoul, Korea.

Park, S. H. (1999). Development of an inventory of functional vocabulary for community functioning of students with mental retardation. Journal of Rehabilitation Research, 3, 23-57.

Park, Y. H. (1996). Core vocabulary for nonverbal elementary school students with cerebral palsy. Korean Journal of Special Education, 13, 91-115.

Park, Y. J. (2009). The relationship between the story structure concept and story-writing of young children (Master's thesis). Wonkwang University, Iksan, Korea.

Shapiro, L. R., \& Hudson, J. A. (1991). Tell me a make-believe story: coherence and cohesion in young children's picture-elicited narratives. Developmental Psychology, 27, 960-974.

Soto, G., \& Hartmann, E. (2006). Analysis of narratives produced by four children who use augmentative and alternative communication. Journal of Communication Disorders, 39, 456-480.

Stuart, S., Vanderhoof, D., \& Beukelman, D. (1993). Topic and vocabulary use patterns of elderly women. Augmentative and Alternative Communication, 9, 95-110.

Trabasso, T., \& Nickels, M. (1992). The development of goal plans of action in the narration of a picture story. Discourse Processes, 15, 249-275.

Waller, A. (2006). Communication access to conversational narrative. Topics in Language Disorders, 26, 221-239.

Yeom, J. S. (1999). Understanding children's world through narrative inquiry: based on the study of children's transition from kindergarten to grade one. Anthropology of Education, 2, 57-82. 
Hye-Jung Song, et al. • Vocabulary Use in Narrative Tasks of Preschoolers

Appendix 1. Number of words for each narrative task

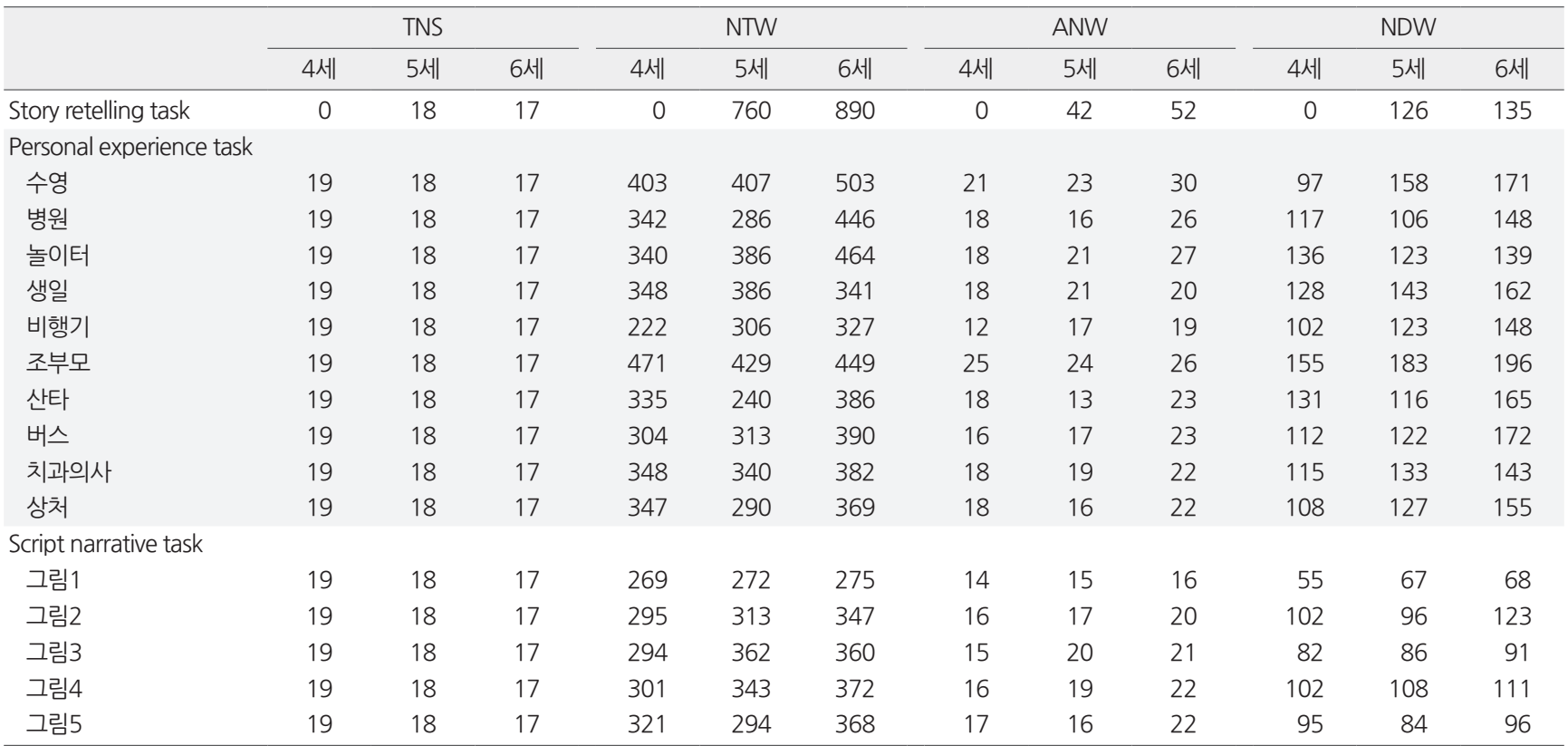

TNS = total number of samples; NTW= number of total words; ANW=average number of words; NDW= number of different words.

Appendix 2. High frequency vocabulary by task type

Task 1. Story retelling task

\begin{tabular}{cccccccc}
\hline No. & Vocabulary & Frequency & $\%$ & No. & Vocabulary & Frequency & $\%$ \\
\hline 1 & 개구리 & 113 & 6.848 & 6 & 하나(인물) & 68 & 4.121 \\
2 & 그래서 & 100 & 6.061 & 7 & 있다 & 64 & 3.879 \\
3 & 엄마 & 96 & 5.818 & 8 & 전화 & 57 & 3.455 \\
4 & 하다 & 86 & 5.212 & 9 & 할머니 & 55 & 3.333 \\
5 & 장화 & 75 & 4.545 & 10 & 그런데 & 42 & 2.545 \\
\hline
\end{tabular}

Task 2. Personal experience task

\begin{tabular}{cccccccc}
\hline No. & Vocabulary & Frequency & $\%$ & No. & Vocabulary & Frequency & $\%$ \\
\hline 1 & 있다 & 415 & 3.807 & 6 & 때 & 249 & 2.284 \\
2 & 하다 & 365 & 3.349 & 7 & 그래서 & 223 & 2.046 \\
3 & 가다 & 349 & 3.202 & 8 & 그리고 & 210 & 1.927 \\
4 & 그런데 & 345 & 3.165 & 9 & 타다 & 210 & 1.927 \\
5 & 나 & 293 & 2.688 & 10 & 엄마 & 137 & 1.257 \\
\hline
\end{tabular}

Task 3. Script narrative task

\begin{tabular}{cccccccc}
\hline No. & Vocabulary & Frequency & $\%$ & No. & Vocabulary & Frequency & $\%$ \\
\hline 1 & 그래서 & 248 & 5.182 & 6 & 먹다 & 129 & 2.695 \\
2 & 있다 & 209 & 4.367 & 7 & 그리고 & 123 & 2.570 \\
3 & 그런데 & 201 & 4.200 & 8 & 주다 & 120 & 2.507 \\
4 & 가다 & 193 & 4.033 & 9 & 솜사탕 & 118 & 2.466 \\
5 & 하다 & 134 & 2.800 & 10 & 토끼 & 107 & 2.236 \\
\hline
\end{tabular}


Appendix 3. High frequency vocabulary by age groups

Story retelling task

\begin{tabular}{|c|c|c|c|c|c|c|}
\hline \multirow{2}{*}{ Rank } & \multicolumn{3}{|c|}{ Group $2(5 ; 0-5 ; 11)$} & \multicolumn{3}{|c|}{ Group $3(6 ; 0-6 ; 11)$} \\
\hline & Vocabulary & Frequency & $\%$ & Vocabulary & Frequency & $\%$ \\
\hline 1 & 개구리 & 55 & 7.227 & 그래서 & 59 & 6.751 \\
\hline 2 & 하다 & 49 & 6.439 & 개구리 & 58 & 6.636 \\
\hline 3 & 엄마 & 44 & 5.782 & 엄마 & 52 & 5.950 \\
\hline 4 & 그래서 & 41 & 5.388 & 전화 & 48 & 5.491 \\
\hline 5 & 장화 & 37 & 4.862 & 장화 & 38 & 4.348 \\
\hline 6 & 있다 & 31 & 4.074 & 하나(인물) & 37 & 4.233 \\
\hline 7 & 하나(인물) & 31 & 4.074 & 하다 & 37 & 3.776 \\
\hline 8 & 번호 & 27 & 3.548 & 있다 & 33 & 3.432 \\
\hline 9 & 할머니 & 25 & 3.285 & 할머니 & 30 & 2.746 \\
\hline 10 & 그런데 & 18 & 2.365 & 그런데 & 24 & 2.403 \\
\hline
\end{tabular}

Personal experience task

\begin{tabular}{|c|c|c|c|c|c|c|c|c|c|}
\hline \multirow{2}{*}{ Rank } & \multicolumn{3}{|c|}{ Group $1(4 ; 0-4 ; 11)$} & \multicolumn{3}{|c|}{ Group $2(5 ; 0-5 ; 11)$} & \multicolumn{3}{|c|}{ Group $3(6 ; 0-6 ; 11)$} \\
\hline & Vocabulary & Frequency & $\%$ & Vocabulary & Frequency & $\%$ & Vocabulary & Frequency & $\%$ \\
\hline 1 & 그런데 & 140 & 4.046 & 있다 & 149 & 4.404 & 있다 & 133 & 3.278 \\
\hline 2 & 있다 & 129 & 3.728 & 하다 & 111 & 3.281 & 가다 & 127 & 3.130 \\
\hline 3 & 하다 & 126 & 3.642 & 가다 & 103 & 3.045 & 하다 & 124 & 3.056 \\
\hline 4 & 가다 & 119 & 3.439 & 그런데 & 91 & 2.690 & 때 & 119 & 2.933 \\
\hline 5 & 나 & 116 & 3.353 & 나 & 84 & 2.483 & 그리고 & 118 & 2.909 \\
\hline 6 & 아니 & 71 & 2.052 & 때 & 79 & 2.335 & 그래서 & 117 & 2.884 \\
\hline 7 & 타다 & 64 & 1.850 & 그래서 & 76 & 2.247 & 그런데 & 114 & 2.810 \\
\hline 8 & 사람이름 & 59 & 1.705 & 타다 & 62 & 1.833 & 나 & 93 & 2.292 \\
\hline 9 & 때 & 51 & 1.474 & 엄마 & 48 & 1.419 & 타다 & 84 & 2.070 \\
\hline 10 & 주다 & 50 & 1.445 & 것 & 47 & 1.389 & 안 & 64 & 1.578 \\
\hline
\end{tabular}

Script narrative task

\begin{tabular}{|c|c|c|c|c|c|c|c|c|c|}
\hline \multirow{2}{*}{ Rank } & \multicolumn{3}{|c|}{ Group $1(4 ; 0-4 ; 11)$} & \multicolumn{3}{|c|}{ Group $2(5 ; 0-5 ; 11)$} & \multicolumn{3}{|c|}{ Group $3(6 ; 0-6 ; 11)$} \\
\hline & Vocabulary & Frequency & $\%$ & Vocabulary & Frequency & $\%$ & Vocabulary & Frequency & $\%$ \\
\hline 1 & 있다 & 65 & 4.392 & 그래서 & 82 & 5.177 & 그래서 & 117 & 6794 \\
\hline 2 & 가다 & 62 & 4.189 & 가다 & 78 & 4.924 & 그런데 & 86 & 4.994 \\
\hline 3 & 그래서 & 49 & 3.311 & 그런데 & 73 & 2.609 & 있다 & 78 & 4.530 \\
\hline 4 & 하다 & 49 & 3.311 & 있다 & 66 & 4.167 & 그리고 & 62 & 3.600 \\
\hline 5 & 먹다 & 43 & 2.905 & 먹다 & 51 & 3.220 & 하다 & 55 & 3.194 \\
\hline 6 & 그런데 & 42 & 2.838 & 하다 & 49 & 3.093 & 가다 & 53 & 3.078 \\
\hline 7 & 주다 & 41 & 2.770 & 주다 & 44 & 2.778 & 솜사탕 & 41 & 2.381 \\
\hline 8 & 토끼 & 40 & 2.703 & 솜사탕 & 38 & 2.399 & 친구 & 37 & 2.149 \\
\hline 9 & 솜사탕 & 39 & 2.635 & 토끼 & 35 & 2.210 & 먹다 & 35 & 2.033 \\
\hline 10 & 고양이 & 34 & 2.297 & 오다 & 34 & 2.146 & 주다 & 35 & 1.858 \\
\hline
\end{tabular}


Hye-Jung Song, et al. • Vocabulary Use in Narrative Tasks of Preschoolers

Appendix 4. Frequency and percent of core word

\begin{tabular}{|c|c|c|c|c|c|c|c|}
\hline No. & Vocabulary & Frequency & $\%$ & No. & Vocabulary & Frequency & $\%$ \\
\hline 1 & 있다 & 688 & 3.969 & 55 & 놀이터 & 50 & 0.288 \\
\hline 2 & 그런데 & 588 & 3.392 & 56 & 오빠 & 50 & 0.288 \\
\hline 3 & 하다 & 585 & 3.374 & 57 & 이빨 & 49 & 0.283 \\
\hline 4 & 가다 & 570 & 3.288 & 58 & 받다 & 48 & 0.277 \\
\hline 5 & 그래서 & 570 & 3.288 & 59 & 수염 & 48 & 0.277 \\
\hline 6 & 그리고 & 351 & 2.025 & 60 & 어린이집 & 47 & 0.271 \\
\hline 7 & 나 & 295 & 1.702 & 61 & 물 & 44 & 0.254 \\
\hline 8 & 엄마 & 289 & 1.667 & 62 & 뛰다 & 43 & 0.248 \\
\hline 9 & 때 & 261 & 1.506 & 63 & 동굴 & 43 & 0.248 \\
\hline 10 & 주다 & 230 & 1.327 & 64 & 머리 & 43 & 0.248 \\
\hline 11 & 보다 & 218 & 1.257 & 65 & 다치다 & 40 & 0.231 \\
\hline 12 & 타다 & 215 & 1.240 & 66 & 치과 & 40 & 0.231 \\
\hline 13 & 것 & 199 & 1.148 & 67 & 유치원 & 39 & 0.225 \\
\hline 14 & 먹다 & 196 & 1.131 & 68 & 가게 & 38 & 0.219 \\
\hline 15 & 할머니 & 165 & 0.952 & 69 & 소시지 & 38 & 0.219 \\
\hline 16 & 오다 & 147 & 0.848 & 70 & 타보다 & 37 & 0.213 \\
\hline 17 & 친구 & 145 & 0.836 & 71 & 다음 & 37 & 0.213 \\
\hline 18 & 집 & 143 & 0.825 & 72 & 비행기 & 37 & 0.213 \\
\hline 19 & 놀다 & 135 & 0.779 & 73 & 크리스마스 & 37 & 0.213 \\
\hline 20 & 할아버지 & 134 & 0.773 & 74 & 이(지시) & 36 & 0.208 \\
\hline 21 & 아빠 & 131 & 0.756 & 75 & 이다 & 36 & 0.208 \\
\hline 22 & 솜사탕 & 118 & 0.681 & 76 & 게임 & 36 & 0.208 \\
\hline 23 & 사람이름 & 114 & 0.658 & 77 & 뚱보 & 36 & 0.208 \\
\hline 24 & 크다 & 114 & 0.658 & 78 & 병원 & 36 & 0.208 \\
\hline 25 & 여기 & 113 & 0.652 & 79 & 이렇게 & 36 & 0.208 \\
\hline 26 & 개구리 & 113 & 0.652 & 80 & 쓰다 & 35 & 0.202 \\
\hline 27 & 안 & 110 & 0.635 & 81 & 잡다 & 35 & 0.202 \\
\hline 28 & 토끼 & 107 & 0.617 & 82 & 케이크 & 35 & 0.202 \\
\hline 29 & 아니 & 107 & 0.617 & 83 & 맨날 & 35 & 0.202 \\
\hline 30 & 그 & 90 & 0.519 & 84 & 어디 & 34 & 0.196 \\
\hline 31 & 같이 & 88 & 0.508 & 85 & 빼다 & 33 & 0.190 \\
\hline 32 & 고양이 & 87 & 0.502 & 86 & 조금 & 33 & 0.190 \\
\hline 33 & 선물 & 87 & 0.502 & 87 & 없다 & 33 & 0.190 \\
\hline 34 & 나다 & 83 & 0.479 & 88 & 요리 & 32 & 0.185 \\
\hline 35 & 되다 & 81 & 0.467 & 89 & 같다 & 32 & 0.185 \\
\hline 36 & 울다 & 77 & 0.444 & 90 & 늦다 & 31 & 0.179 \\
\hline 37 & 장화 & 75 & 0.433 & 91 & 번 & 31 & 0.179 \\
\hline 38 & 그러면 & 74 & 0.427 & 92 & 아이 & 31 & 0.179 \\
\hline 39 & 그냥 & 73 & 0.420 & 93 & 많다 & 31 & 0.179 \\
\hline 40 & 아프다 & 72 & 0.415 & 94 & 자다 & 30 & 0.173 \\
\hline 41 & 생일 & 70 & 0.404 & 95 & 해주다 & 30 & 0.173 \\
\hline 42 & 버스 & 69 & 0.398 & 96 & 수영장 & 30 & 0.173 \\
\hline 43 & 하나(인물) & 68 & 0.392 & 97 & 약 & 30 & 0.173 \\
\hline 44 & 들어가다 & 63 & 0.363 & 98 & 피 & 30 & 0.173 \\
\hline 45 & 그네 & 60 & 0.346 & 99 & 두 & 29 & 0.167 \\
\hline 46 & 비 & 60 & 0.346 & 100 & 넘어지다 & 29 & 0.167 \\
\hline 47 & 재미 & 58 & 0.335 & 101 & 사주다 & 29 & 0.167 \\
\hline 48 & 다 & 58 & 0.335 & 102 & 화나다 & 29 & 0.167 \\
\hline 49 & 전화 & 57 & 0.329 & 103 & 밤 & 29 & 0.167 \\
\hline 50 & 사다 & 56 & 0.323 & 104 & 번호 & 29 & 0.167 \\
\hline 51 & 미끄럼틀 & 56 & 0.323 & 105 & 못 & 29 & 0.167 \\
\hline 52 & 산타 & 55 & 0.317 & 106 & 놓치다 & 28 & 0.162 \\
\hline 53 & 좋다 & 55 & 0.317 & 107 & 물고기 & 28 & 0.162 \\
\hline 54 & 맞다 & 50 & 0.288 & 108 & 부딪히다 & 27 & 0.156 \\
\hline
\end{tabular}


Appendix 4. Continued

\begin{tabular}{|c|c|c|c|c|c|c|c|}
\hline No. & Vocabulary & Frequency & $\%$ & No. & Vocabulary & Frequency & $\%$ \\
\hline 109 & 낙서 & 27 & 0.156 & 161 & 더 & 16 & 0.092 \\
\hline 110 & 사람 & 27 & 0.156 & 162 & 맛있다 & 16 & 0.092 \\
\hline 111 & 뽑다 & 26 & 0.150 & 163 & 앞 & 15 & 0.086 \\
\hline 112 & 춥다 & 26 & 0.150 & 164 & 열 & 15 & 0.086 \\
\hline 113 & 밖 & 25 & 0.144 & 165 & 형 & 15 & 0.086 \\
\hline 114 & 생선 & 25 & 0.144 & 166 & 잘 & 15 & 0.086 \\
\hline 115 & 옛날 & 25 & 0.144 & 167 & 한 & 14 & 0.081 \\
\hline 116 & 무섭다 & 25 & 0.144 & 168 & 거기 & 14 & 0.081 \\
\hline 117 & 어떤 & 24 & 0.138 & 169 & 가보다 & 14 & 0.081 \\
\hline 118 & 나가다 & 24 & 0.138 & 170 & 나오다 & 14 & 0.081 \\
\hline 119 & 녹다 & 24 & 0.138 & 171 & 잃어버리다 & 14 & 0.081 \\
\hline 120 & 놓다 & 24 & 0.138 & 172 & 애 & 14 & 0.081 \\
\hline 121 & 붙이다 & 24 & 0.138 & 173 & 치료 & 14 & 0.081 \\
\hline 122 & 구름 & 24 & 0.138 & 174 & 낫다 & 14 & 0.081 \\
\hline 123 & 밴드 & 24 & 0.138 & 175 & 가지다 & 13 & 0.075 \\
\hline 124 & 연못 & 24 & 0.138 & 176 & 걷다 & 13 & 0.075 \\
\hline 125 & 뭐 & 23 & 0.132 & 177 & 젖다 & 13 & 0.075 \\
\hline 126 & 언제 & 23 & 0.132 & 178 & 길 & 13 & 0.075 \\
\hline 127 & 나타나다 & 23 & 0.132 & 179 & 남자 & 13 & 0.075 \\
\hline 128 & 아침 & 23 & 0.132 & 180 & 상처 & 13 & 0.075 \\
\hline 129 & 장난감 & 23 & 0.132 & 181 & 애 & 13 & 0.075 \\
\hline 130 & 튜브 & 23 & 0.132 & 182 & 하늘 & 13 & 0.075 \\
\hline 131 & 새다 & 22 & 0.127 & 183 & 그렇다 & 13 & 0.075 \\
\hline 132 & 찍다 & 22 & 0.127 & 184 & 물어보다 & 12 & 0.069 \\
\hline 133 & 선생님 & 22 & 0.127 & 185 & 올라가다 & 12 & 0.069 \\
\hline 134 & 차 & 21 & 0.121 & 186 & 동생 & 12 & 0.069 \\
\hline 135 & 파티 & 21 & 0.121 & 187 & 이(신체) & 12 & 0.069 \\
\hline 136 & 이거 & 20 & 0.115 & 188 & 주사 & 12 & 0.069 \\
\hline 137 & 걸리다 & 20 & 0.115 & 189 & 다시 & 12 & 0.069 \\
\hline 138 & 따라가다 & 20 & 0.115 & 190 & 떨어지다 & 11 & 0.063 \\
\hline 139 & 앉다 & 20 & 0.115 & 191 & 빨다 & 11 & 0.063 \\
\hline 140 & 찾다 & 20 & 0.115 & 192 & 결혼식 & 11 & 0.063 \\
\hline 141 & 명 & 20 & 0.115 & 193 & 공부 & 11 & 0.063 \\
\hline 142 & 전화번호 & 20 & 0.115 & 194 & 누나 & 11 & 0.063 \\
\hline 143 & 너무 & 20 & 0.115 & 195 & 물놀이 & 11 & 0.063 \\
\hline 144 & 던지다 & 19 & 0.109 & 196 & 또 & 11 & 0.063 \\
\hline 145 & 만나다 & 19 & 0.109 & 197 & 빨리 & 11 & 0.063 \\
\hline 146 & 감기 & 19 & 0.109 & 198 & 하나 & 11 & 0.063 \\
\hline 147 & 당근 & 19 & 0.109 & 199 & 다니다 & 10 & 0.058 \\
\hline 148 & 참다 & 18 & 0.104 & 200 & 도망가다 & 10 & 0.058 \\
\hline 149 & 개 & 18 & 0.104 & 201 & 썩다 & 10 & 0.058 \\
\hline 150 & 손 & 18 & 0.104 & 202 & 알려주다 & 10 & 0.058 \\
\hline 151 & 아기 & 18 & 0.104 & 203 & 로봇 & 10 & 0.058 \\
\hline 152 & 야옹이 & 18 & 0.104 & 204 & 문 & 10 & 0.058 \\
\hline 153 & 제주도 & 18 & 0.104 & 205 & 유치원 & 10 & 0.058 \\
\hline 154 & 내리다 & 17 & 0.098 & 206 & 코 & 10 & 0.058 \\
\hline 155 & 바르다 & 17 & 0.098 & 207 & 학교 & 10 & 0.058 \\
\hline 156 & 사진 & 17 & 0.098 & 208 & 계속 & 10 & 0.058 \\
\hline 157 & 텔레비전 & 17 & 0.098 & 209 & 무릎 & 9 & 0.052 \\
\hline 158 & 날 & 16 & 0.092 & 210 & 생각 & 9 & 0.052 \\
\hline 159 & 살 & 16 & 0.092 & 211 & 시소 & 9 & 0.052 \\
\hline 160 & 쪽 & 16 & 0.092 & 212 & 막 & 9 & 0.052 \\
\hline
\end{tabular}


Hye-Jung Song, et al. • Vocabulary Use in Narrative Tasks of Preschoolers

Appendix 5. Fringe vocabulary

\begin{tabular}{|c|c|c|c|c|c|}
\hline \multirow{2}{*}{$\frac{\text { Category }}{\text { 활동 및 경헝 }}$} & \multicolumn{5}{|c|}{ Example } \\
\hline & 술래잡기 & 축구 & 딱지 & 물총 & 숨바꼭질 \\
\hline & 발레 & 고무줄 & 알레르기 & 영어뮤지컬 & 캠핑 \\
\hline \multirow[t]{2}{*}{ 특정인물 및 캐릭터 } & 외할아버지 & 도둑 & 경찰관 & 삼촌 & 이모 \\
\hline & 티라노사우루스 & 단군할아버지 & 라푼젤 & 수지 & 사촌 \\
\hline \multirow[t]{2}{*}{ 장소 } & 시골 & 키즈카페 & 흙놀이터 & 말레이시아 & 파리바게트 \\
\hline & 홈플러스 & 양평 & 워터파크 & 서점 & 성심병원 \\
\hline \multirow[t]{2}{*}{ 소유물 } & 레고 & 라바 & 뽀로로 & 또봇 & 목도리 \\
\hline & 컴퓨터 & 목걸이 & 가방 & 라바인형 & 점퍼 \\
\hline \multirow[t]{2}{*}{ 음식 } & 떡볶이 & 귤 & 사탕 & 블루베리 & 오징어 \\
\hline & 아이스크림 & 도넛 & 파인애플 & 햄버거 & 시금치 \\
\hline \multirow[t]{2}{*}{ 상태 표현 } & 바뀌다 & 망가지다 & 시들다 & 슬프다 & 심하다 \\
\hline & 조그맣다 & 고맙다 & 관찮다 & 썩다 & 속상하다 \\
\hline \multirow[t]{2}{*}{ 동작 표현 } & 놀리다 & 때리다 & 빼주다 & 쫓아가다 & 깨물다 \\
\hline & 뜷리다 & 뱉다 & 없애다 & 할퀴다 & 튀기다 \\
\hline
\end{tabular}




\title{
국문초록
}

\author{
학령전기 아동의 내러티브 과제에서 나타나는 어휘사용 특성: AAC 적용을 위한 기초연구 \\ 송혜정 $\cdot$ 송양민 ${ }^{2} \cdot$ 박현주 $1^{1}$ \\ '가천대학교 특수치료학과 언어치료전공, ${ }^{2}$ 가천대학교 헬스케어경영학과
}

배경 및 목적: 보완대체 의사소통 영역에서 어휘 관련 연구가 꾸준히 이루어져왔음에도 불구하고, 어린 아동 대상의 어휘 연구는 찾아 보기 어렵다. 본 연구에서는 학령전기 아동을 대상으로 내러티브 발화를 수집하여 낱말 단위로 분석한 후 어휘 사용 양상을 살펴보고 자 하였다. 방법: 연구대상은 4-6세 일반아동 53명(남 26명, 여 27명)으로, 이들은 3가지 내러티브 산출과제(이야기 다시 말하기, 개인적 경험 말하기, 이야기 구성하기)를 수행하였다. 산출된 발화는 과제유형과 연령집단에 따른 고빈도 어휘, 전체어휘에서 핵심어휘가 차지 하는 비율, 핵심어휘에서 나타나는 구조어와 내용어의 비율, 전체 과제에서 나타나는 부수어휘 및 비율 등으로 분석하였다. 결과: 고빈 도 어휘는 과제 및 연령의 영향을 받는 것으로 나타났으며, 핵심어휘는 전체낱말의 $72 \%$ 를 차지하여 소수의 핵심어휘가 전체어휘의 많 은 부분을 대표하는 것으로 나타났다. 또한 구조어와 내용어의 비율은 19:81로 내용어가 차지하는 비율이 월등히 높은 반면, 부수어휘 가 전체낱말에서 차지하는 비율은 $7.45 \%$ 로 낮게 나타났다. 논의 및 결론: 어린 아동의 어휘 사용은 과제의 영향을 크게 받음을 확인하 였다. 대화체가 아닌 긴 이야기를 수집하여 학령전기 아동의 핵심어휘 목록을 제시하였다는 데 의의가 있다.

핵심어: 보완대체 의사소통, 내러티브, 핵심어휘, 부수어휘

본 연구는 제 1 저자의 석사학위논문을 수정·보완하였음.

\section{참고문헌}

김영태, 박현주, 민홍기(2003). 보완·대체의사소통도구 개발을 위한 학령기 아동 및 성인의 핵심어휘 조사. 언어청각장애연구, 8, 93-110.

김영태, 홍경훈, 김경희, 장혜성, 이주연(2009). 수용표현어휘력검사(REVT). 서울: 서울장애인종합복지관.

김홍남(2013). 유치원의 경험 이야기나누기 활동에서 나타난 만 3 세반 유아의 일상적 내러티브 특징 연구. 한국교원대학교대학원 석사학위논문.

박승희(1999). 정신지체학생의 지역사회 기능에 필요한 기능적 어휘 목록 개발연구. 재활복지, 3, 23-57.

박은주(2009). 만 3,4,5세 유아들의 이야기 구조 개념 발달과쓰기 발달간의 관계. 원광대학교대학원 석사학위논문.

박은혜(1996). 보완대체 의사소통체계를 위한 기초어휘조사: 뇌성마비 초등 저학년을 중심으로. 특수교육논총, 13, 91-115.

박혜연(2009). 그룹홈 거주 지적장애성인의 핵심어휘 및 부수어휘 분석을 통한 의미적 언어사용 연구. 이화여자대학교대학원 석사학위논문.

염지숙(1999). 내러티브 탐구를 통한 유아 세계 이해: 유치원에서 초등학교 1학년으로의 전이 경험 연구를 중심으로. 교육인류학연구, 2, 57-82.

이영미, 김영태, 박은혜(2005). 학령기 아동의 학교상황 어휘 연구: AAC 적용을 위한 기초연구. 언어청각장애연구, 10, 134-152.

이형진(2003). 하나가 길을 잃었어요. 서울: 시공주니어.

이흔정(2004). 내러티브의 교육과정적 의미 탐색. 교육학연구, 10, 151-170.

천춘경(2000). 보완. 대체 의사소통(AAC)체계 활용을 위한 지역 사회 중심의 기초 어휘 및 문장 조사. 단국대학교대학원 석사학위논문.

최윤정, 한동옥(2013). 1세 영아의 그림책 읽기 과정에 나타난 개인적 내러티브 사례연구. 어린이문학교육연구, 14, 375-397. 